\title{
Animals as Magical Ingredients in Greek Magical Papyri: Preliminary Statistical Analysis of Animal Species
}

Andrea Salayová

\begin{abstract}
The focus of this study, which is based on a detailed analysis of Greek magical papyri, is to research, how the animal ingredients were used within the sphere of magic in the antiquity and what further information can be drawn. This paper serves as a preliminary review of the results provided by the statistical analysis. Main research questions are: How many papyri spells contain at least one animal ingredient? Which animals were used the most as an ingredient? Which animal body parts were prevalent in papyri spells? Were the animal body parts used in spells chosen based on analogy? Answering these questions can help us understand the connection of animals to magic, and determine if some animals were considered to have more magical power than others. A key source for this study was Betz's edition of The Greek magical papyri from 1986, compared to Preisendanz's Papyri Graecae magicae: Die griechischen Zauberpapyri from 1928.
\end{abstract}

\section{Keywords}

ancient magic; Greek magical papyri; animals in antiquity 


\section{Introduction}

In antiquity, there were numerous uses for animals within the magical and religious sphere. In the latter, animals were mostly used for two main purposes - divination ${ }^{1}$ and as a religious sacrifice. ${ }^{2}$ Ogden (2014: pp. 294-309), based on the information provided by Greek and Roman literature, mentions four categories of the use of animals in the sphere of magic: transformation of humans into animals, use of animals for magical purposes, deployment of magic against animals, and deployment of magic by animals against man. Contrary to Ogden and his research of literature, my study concentrates on the Greek magical papyri, which are considered a primary source of our information about magic in antiquity. Within this technical literature, we can find the use of animals within the sphere of magic, either as part of healing spells or recipes, or as part of aggressive magic, aimed to manipulate or hurt the victim of the spell. Animals in these spells can be used as ingredients within the recipe, or as a sacrifice required to perform the spell.

\section{Magic vs. religion}

Even though this research is aimed at use of animal ingredients in magic, it is very difficult to determine what exactly magic is from the point of view of the antiquity. As Johnston (2007: pp. 139-152) remarks: "In antiquity, magic (...) almost always referred to someone else's religious practices". ${ }^{3}$ There is no clear correlation between magic and religion in antiquity, if one exists at all.

The relationship between the terms magic and religion has proven problematic to say the least. Various scholars have touched on this subject, but there is no exact definition (or difference) as far as terminology goes, since "magic was almost always a normative, rather than straightforwardly descriptive, term..." (Johnston 2007: p. 141). This problem has been thoroughly researched by Versnel (1991), who comments that even there have been opinions stating it not possible to distinguish between the two terms: “... rejection of the term 'magic' will soon turn out to be unworkable". ${ }^{4}$ According to Versnel, some differences were obvious even to classical authors. ${ }^{5}$ He uses four important points in determining them: Intention, Attitude, Action and Social/Moral evaluation. Intention of magical performance is to "achieve concrete, mostly individual goals". ${ }^{6}$ Attitude of magic is manipulative and while performing the Action of magic, the emphasis is on the

\footnotetext{
1 Struck (2014).

2 Ekroth (2014).

3 Johnston (2007: p. 140).

4 Versnel (1991: p. 177).

5 Versnel (1991: p. 177).

$6 \quad$ Versnel (1991: p. 178).
} 
"technical side of the manipulation, precision of formula and modus operandi". ${ }^{7}$ Lastly, magic is often considered anti-social or immoral because "the goals of magic often run counter to the interests of other members of the society". ${ }^{8}$ While this distinction cannot be applied to every case, it certainly proves helpful within the boundaries of specific research of magic, where some type of distinction terminology is necessary. Otto (2013) states: "Thus, to date, the term 'magic' still serves as a concept widely used to signify and classify specific source material in the Study of Classical Antiquity". ${ }^{9} \mathrm{He}$ stresses the importance to differentiate between modern understanding of magic and what this concept meant in antiquity. ${ }^{10}$ The problems with the terminology concerning magic have been well summarized by Dickie (2003: pp. 18-46) on an example of the student studying ancient magic: "He is, furthermore, studying the societies that gave birth to the concept of magic with which modern Western man operates. He needs, however, to be sensitive to the differences that exist between what the ancients saw as magic and what he himself might be inclined to call magic". ${ }^{11}$

When it comes to Greek magical papyri, this problem could be translated into a dispute whether texts contained in them belong to the magical sphere or were intended for the mystery cults. As Betz (1997) states: "For the Papyri Graecae Magicae there is no distinction between magic and mystery cult". ${ }^{12}$ So even if it might seem like mystery cults could be connected to religion more than they were connected to magic, this kind of distinction simply did not exist in the antiquity. As Otto (2013) states: "Beyond the words and independent of academic controversies, ancient "magic" is (and was, respectively) real and, as such, needs to be properly investigated". ${ }^{13}$

\section{Greek magical papyri}

Even though we know of more ancient texts, inscriptions like defixiones on lead tablets and various amulets, magical gems, and so called kolossoi (magical poppets) which can be considered belonging to the sphere of magic, ${ }^{14}$ Greek magical papyri have a special place among them because of the number, structure, and details of magical rituals they include.

These magical texts were found in Egypt, but are written in Greek and Coptic. They are dated from $2^{\text {nd }}$ century BCE to $5^{\text {th }}$ century $\mathrm{CE} .{ }^{15}$ They contain a variety of genres,

7 Versnel (1991: p. 179).

8 Versnel (1991: p. 179).

9 Otto (2013: p. 310).

10 For more on understanding and development of the term magic in antiquity see Dickie (2003: pp. 18-45).

11 Dickie (2003: p. 20).

12 Betz (1997: p. 249).

13 Otto (2013: p. 310).

14 As other main primary sources on magic in antiquity can be considered numerous curse tablets, see Audollent (1904), Gager (1992), Urbanová (2014), greek - Wünsch (1897), or various magical gems - Michel (2001), Bonner (1950), for kolossoi see Faraone (1991), Sánchez Natalías (2015).

15 Betz (1986: p. 41). 
like hymns, magical formulae, descriptions of rituals, and numerous parts of the spells, each with varying length and amount of detail. The nature of these spells is also different from one spell to another. We can find spells for acquiring an assistant daimon (e.g. PGM I. 1-42), spells for invisibility (e.g. PGM I. 222-231), various love spells (e.g. PGM IV. 1390-1495), prayers to various gods (e.g. PGM IV. 2785-2890), oracles for divinatory purposes (e.g. PGM IV. 3086-3124), charms to being loved or to obtain better vision (e.g. PGM VII. 300a-310), spells for finding a thief (e.g. PGM III. 488-494) and many more. ${ }^{16}$ Animal ingredients can be found in the majority of these texts, which suggests that they were very versatile.

Unlike accounts of classical authors, which were informative and not intended for performers of magic, Greek magical papyri were supposed to be used as some sort of recipe, so they focus on practical use and description of the steps that are needed in performing the magical ritual, which means they are much more detailed than secondary accounts of classical authors.

\section{An example of a papyri spell with animal ingredients}

For an example of a spell referring to magical ingredients there is PGM I. 247-262, titled as Invisibility spell. It was chosen as an example for its typical composition in form, but also in content. The spell begins with a title and commentary of the mage: "Tested spell for invisibility". The author uses the word "tested" to give the spell more believability, probably in order to appeal to those who have doubts about its effectiveness. Then we can see the list of the ingredients and description of the steps needed to be taken in order to successfully perform the ritual. The next part of the spell is the invocation of Egyptian divine powers, in which the performer is supposed to appeal to the gods or daimons and secure their favor. Within the invocation section we can find voces magicae, obscure words seemingly without meaning. Some of them may have been the names of daimons or lesser gods we are not familiar with today, or the obscure character of the words helps with the magical atmosphere of the spell. The performer is also supposed to say his name (I, NN, where NN should be substituted with the name) to avoid some possible confusion. The spell ends with the description of steps, which are needed to reverse its effect - invisibility.

In this case, there is the eye of an ape as an animal ingredient, used only in this specific spell. ${ }^{17}$ Another four spells however, contain other parts of the ape as the ingredients (2X excrements, 1X blood and 1X so called "magical material"). Interesting is the use of an eye in connection to invisibility - we have only two of these spells in this collection of papyri, but both of them list an eye as the ingredient (another is PGM I. 222-231 which

16 For complete list of spells see the Betz's Table of spells in Betz (1986: p. XI).

17 Specifically, the spell calls for either the eye of an ape or the eye of a corpse - this duality of ingredients is very common in the papyri spells, it gives the illusion of better accessibility to the ingredients by simply giving the performer the choice of two or more ingredients to use. 
lists the eye of an owl). This suggests that selection of animal ingredients for the spells was not accidental and the principle of analogy was being used.

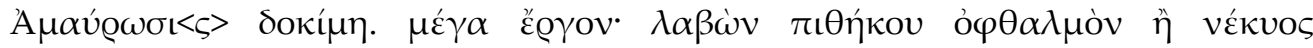

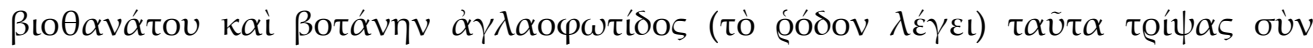

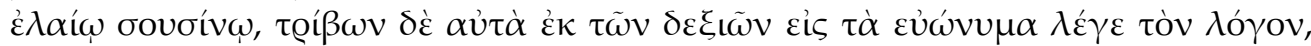

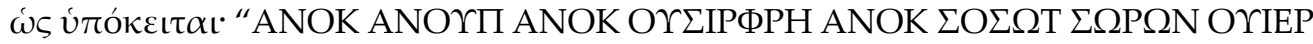

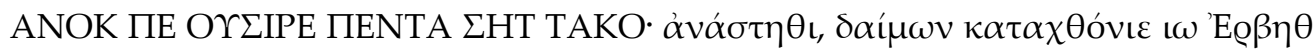

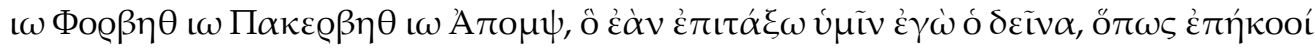

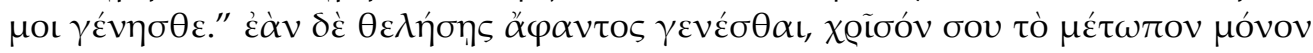

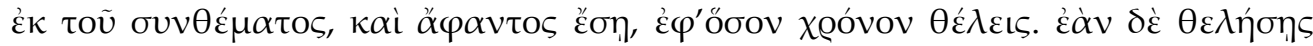

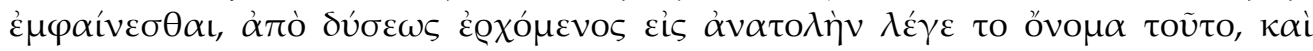

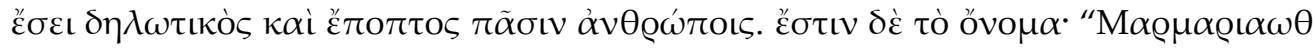

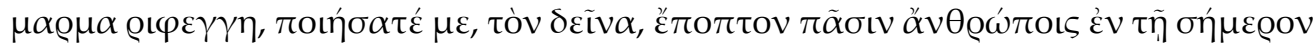

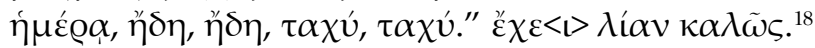

“*Tested spell for invisibility: A great work. Take an eye of an ape or of a corpse that has died a violent death and a plant of peony (he means the rose). Rub these with oil of lily, and as you are rubbing / them from the right to the left, say the spell as follows: I am ANUBIS, I am OSIR-PHRE, I am OSOT SORONOUIER, I am OSIRIS whom SETH destroyed. Rise up, infernal daimon, ${ }^{19}$ IO ERBETH IO PHOBETH IO PAKERBETH IO APOMPS; whatever I, NN, order you to do, / be obedient to me. And if you wish to become invisible, rub just your face with the concoction, and you will be invisible for as long as you wish. And if you wish to be visible again, move from west to east and say this name, and you will be obvious and visible to all men.” (Betz 1986: pp. 9-10).

\section{Animal ingredients in Greek magical papyri}

\section{Number of papyri spells with animal ingredient}

The focus of this study, however, is the use of animal ingredients in these spell-recipes. The first question that arises regarding this topic is how many of the papyri-spells contain some kind of animal ingredient. Out of the all 532 Greek magical papyri-spells in the collection by Betz from 1986, 142 contain at least one animal ingredient, which is approximately 27\%. ${ }^{20}$ This number could be higher if all the published papyri were complete, but some of them are just fragments and their unknown parts could possibly also contain animal ingredients. In these 142 papyri we can find 52 different kinds of animals - 18 different kinds of birds (falcon, owl, ibis, hoopoe, rooster, chicken, pigeon,

18 Preisendanz (1973: p. 14).

19 For more on "divine helpers" in PGM see Ciraolo (2001).

20 For chart demonstration see Figure 1. 
dove, turtle-dove, vulture, goose, crow, partridge, wren, quail, hawk, nightjar, and swallow), 22 kinds of mammals (monkey, wolf, ram, sheep, goat, cat, cow, horse, donkey, mule, mouse, rat, dog, bat, pig, hare, hyena, weasel, camel, deer, doe, antelope), 5 kinds of insects (scarab, bug - unspecified kinds of insects, fly, wasp, tick), 4 kinds of reptiles or amphibians (snake, lizard, frog, crocodile), and 3 kinds of fish or water arthropods (eel, silurus, crab). The majority of these species could be considered wild (38 out of 52 species), so the accessibility to domesticated species was likely not the main factor in the selection of animal ingredients. This high variety of animals suggests either that all animals were considered to have magical properties, or that the choice of certain animals depended more on attributes and appearance of the animal (or its perceived magical powers), than its species. Some animals however, are being used more frequently than others. Could this simply be because of easier accessibility to certain species, the higher population of this species, its lower price on the market or were there species, which were simply attributed more magical power than the others? Unfortunately, there is no direct answer to this question, but these factors might have played some role in the selection of animal ingredients for the spells.

\section{Animal ingredients by species}

The results of this research show that, as expected, a number of certain species of animals used as ingredients in papyri-spells, ranked from the most frequently used to the least frequently used, are slowly declining without any significant leaps. Except for the most used animal in the Greek magical papyri as an ingredient, which is present in twice as many papyri as any other. We would expect this animal to be widely known for its "magical" properties even today. The most used animal in papyri is Equus africanus asinus or simply said - donkey. Donkey-related ingredients can be found in 23 out of 142 papyri with animal ingredients. Second on the list of most used animals in papyri-spells is a more typical "magical" animal from modern perspective - a lizard, with its presence in 14 out of 142 papyri. Third most used animal is the rooster in 13 papyri-spells, fourth the goat with 12 , fifth the ibis-bird with 10 , and the cow equally at 10 . Falcon and scarab are present in 9 papyri-spells, hoopoe in 8 , mouse and pig both in 6 , and dove, goose, hawk, monkey, ram, wolf, sheep, cat, dog, bat, hyena, weasel, bug, and frog are each present in 5 papyri spells. Owl, thick, snake and crocodile are present in 4 papyri spells, chicken, pigeon, crow, horse, wasp, and eel in 3 papyri spells. Nightjar, mule, hare, and crab are present in 2 papyri spells, and all of the other animal species (turtle-dove, vulture, partridge, wren, quail, swallow, rat, camel, deer, doe, antelope, fly and silurus) are present in 1 papyri-spell. ${ }^{21}$

So why is donkey used more often than any other animal?

21 See Figure 2 for statistical results and chart demonstration of the presence of animal ingredients by species in papyri spells. 


\section{Possible reasons for prevalence of some species}

As previously stated, one of the reasons for the prevalence of donkey ingredients could have been easy access to this animal. Donkeys were popular livestock animals among all the Mediterranean nations in antiquity. Most of the papyri required the part of the donkey which would not necessary mean killing it for the magician to use it (for example blood in smaller amounts, tooth, cerumen from the ear, etc.). Compared to some other animals, it might be easier to get access to a donkey. There are more domesticated animals that also fit this description and we can find them in far fewer papyri (for example sheep-ingredient is present in only 5 out of 142 papyri). So, easy accessibility could have mattered, but there must have also been another reason (or more of them), why donkey stands out so much.

Interestingly, the history of domestication of this animal might have started in ancient Egypt, ${ }^{22}$ where most of the papyri come from. "In the Dynasty IV era of Egypt, between 2675 and $2565 \mathrm{BC}$, wealthy members of society were known to own over 1,000 donkeys, employed in agriculture, as dairy and meat animals and as pack animals". ${ }^{23}$ It was connected to numerous gods in the antiquity (for example Egyptian sun-god Ra, Typhon, or Seth, who was also often depicted with the head of a donkey). ${ }^{24}$ With its wide use within the sphere of magic, would the literature reflect this state? One notable example of portraying a donkey in connection to magic can be found in Apuleius' Golden Ass. However, it is debatable, if the choice of the animal was made by its connection to magic or if it was because of its other characteristics, especially those concerning its temperament - stubbornness, foolishness and low class. These characteristics are also typical for representation of donkeys in Aesop's fables, where it acts foolishly in more than 20 of them, which is also reflected in the Phaedrus's saying Asinus ad lyram (Phaed. Appendix 12). ${ }^{25}$ In translation, this means "donkey to the lyre", which is used to describe the incompetent person.

I would suggest, that use of donkey in such a significant number of papyri is a result of a combination of factors, mostly its accessibility and mythologic-economical background. According to Kitchell (2014: pp. 57-59), a donkey was much less expensive than a horse and was considered "poor person's equivalent of a horse" ${ }^{26} \mathrm{He}$ also states, that donkeys could be compared to slaves and just as the slaves they were often abused, which is also found in Homer's sole reference to this animal - it is pictured as being beaten by children (Il.11.558f.). The donkey's connection to religion and Egyptian mythology however, could have been the key factor for its prevalence, since the papyri themselves come

\footnotetext{
22 Rossel et al. (2008).

23 Olsen (1996).

24 Bough (2011: p. 65).

25 Brodňanská (in print).

26 For more see Kitchell (2014: pp. 57-59).
} 
from Egypt and "in accordance with their geographical place of origin, the materials in the Papyri Graecae Magicae continue the older Egyptian magic". ${ }^{27}$

Lizard is the animal that was (and still is) more obviously connected to magic, from the modern point of view (and its presence in the magical folklore). ${ }^{28}$ Could it be its ability to grow a tail after it has been removed, or its general preference of cold and dark places, that could have led people to these beliefs? It was also a very common animal, with 17 of its species present in Italy and 19 in Greece (Kitchell 2014: p. 111). This could have meant easier accessibility, which could have led to its higher use as an ingredient in magic. Kitchell also states, that "They were common ingredients in magic potions ... They enhanced erotic spells ..., could aid eyesight ..., and four geckos dissolved in sugar made a nice aphrodisiac if spread over the right big toe, whereas an application to the left big toe canceled the effect...”. This very much corresponds with it being the second most used ingredient in PGM. They are indeed associated with erotic spells (PDM LXI. 197-216 titled Love spell of attraction ${ }^{29}$ uses whole lizard, PDM LXI. 112-127 titled Prescription for making a woman love $e^{30}$ calls for the lizard's bone). Pliny's statement about helping the eyesight can also be confirmed by papyri-spell (PGM XCVII. 1-6 titled Spell against eye disease $e^{31}$ calls for the eye of the lizard).

Statistically, there are no other animal species prevalent in PGM. It was expected that other domesticated animals would be present, which has proved to be true, but no other domesticated species is present in papyri spells in the same number of cases as donkey.

\section{Animal body parts as the ingredients in papyri-spells}

So which parts of the animals were mostly required for the papyri-spells? Again, these parts were ranked based on the number of papyri-spells they appear in. On the top of the list, found in 76 out of 142 papyri containing animal ingredients, is the animal's body as a whole. This was caused by widespread requirement of whole animal being used as an offering within the spell. Out of every instance of animal being used as an ingredient in Greek magical papyri, 15,5\% of them are used as the offering, in the same

27 Betz (1997: p. 249).

28 For more see Versnel (2002: p. 149).

29 "*Love spell of attraction: It attracts a woman who has been wronged by her husband. / Take from the place where bodies are mummified a spotted lizard which lives around those places, and throw the same lizard into an iron vessel, and // take coals from the forge whenever they light the fire and put them into the vessel with the lizard, bum it up on the coals and while doing it say: ...” (Betz 1986).

30 "*A prescription for making a [woman] love you: An image of Osiris [made] of wax - you should ..., you bringing hair (?) and [wool] of a donkey together with a bone of a lizard. / You should [bury them under the] doorsill of her house. If stubbornness occurs, you should bring it ... the image of Osiris with (?) ram's wool; you should put the lizard bone ...; / you should bury it again under the doorsill of her house; and you should recite before Isis in the evening when the moon has risen. Listen before you bury..." (Betz 1986).

31 "[Another:] Cut out the right [eye] of a lizard and / [enclose it] in [goat skin]; attach it to [your] left [eye]." (Betz 1986). 
way we know from the religious sphere. Sometimes, there are further requirements for the offering animal, mostly regarding its colour, in most cases white, which is called for in 7 papyri-spells - PGM IV. 3125-3171 (falcon with white face), PGM XIII. 343-646 (white rooster), PGM IV. 2145-2240 (white rooster), PGM VII. 478-490 (white dove), PGM IV. 2891-2942 (white dove), PGM XII. 201-269 (white goose), PGM IV. 2373-2440 (donkey with white forehead). In other cases, black animal is required as the offering (4 papyri-spells) - PGM CXXIX. 1-7 (black wolf), PGM VII. 528-539 (black ram), PGM IV. 1275-1322 (black sheep), PGM IV. 1331-1389 (black donkey). But not every animal used as a whole is used as the offering. They serve various purposes as a part of the spell, but one of the most common uses of whole animal in papyri-spells is as offering.

The second most used animal part is blood. This ingredient is present in 46 out of 142 papyri-spells with animal ingredients. Again, similar to the situation with the animal species, this number is significantly higher compared to other animal parts. This might have been caused by the belief that blood is a carrier of life-energy and therefore powerful ingredient to be used in spells. Bremmer (2007) remarks, that blood was often used as a form of purification, especially against mold and leprosy, which is attested in The Holy Bible (Lev. 14). He also states that "In Babylon, the blood of a suckling pig was spattered on the bed of a person possessed by an evil spirit, whereas in Greece deranged people themselves could apparently be showered with the blood of slaughtered piglet. Perhaps we find here the idea of blood as life-giving substance that could revive people or houses in a controlled ritual context" (Bremmer 2007: p. 41). In PGM, there is one instance of a spell calling for the blood of a pig - PGM IV. 3255-3274, titled Spell to induce insomnia. ${ }^{32}$

Interestingly, in PGM the blood of birds is required much more often, especially blood of hoopoe and blood of dove. We can find hoopoe ingredient in 8 papyri-spells and 5 of them require hoopoe blood, and out of 5 papyri-spells with dove ingredients, 4 of them require dove's blood. The numbers of hoopoe or dove ingredients in PGM are not high enough for it to be possible to draw some statistically relevant conclusions.

Third and fourth on the list (see Figure 3), both with its presence in 15 out of 142 papyri-spells, are animal excrements ${ }^{33}$ and skin. Then numbers are slowly declining, without any more drastic leaps, which was to be statistically expected. Fifth and sixth on the list are bile and fat, each used in 12 papyri-spells, then egg, used in 11 papyri-spells, hair, used in 8 papyri-spells, head, in 7 papyri-spells, then heart and brain, each in 6 papyrispells, feather and eye, each in 5 papyri-spells, tooth and tongue, each in 4 papyri-spells, wing, "magical material" 34 and hoof, each in 3 papyri-spells, knuckle, rib and wool, each

32 “Take an unbaked [brick] and with a bronze stylus draw an [ass] running, and on its face 'IAO O,' and on its neck in the shape of a little bell 'EOEOE,' and on its back 'LERTHEMINO,' and on its breast '[S] ABAOTH,' and under its hooves 'ABRASAX.' / Smear it with the blood of Typhon and a pig and with juice of an onion."

33 Unfortunately, there is no further information in PGM on how the excrements were supposed to be collected or handled.

34 Any material from the animal, that was considered having magical powers and represented the animal in the spell. 
in 2 papyri spells and stomach stone, windpipe, umbilical cord, tear, tail, snout, mucus, mouth-foam, spine, placenta, skull, ear-wax, lungs, leg, bone, each present in 1 papyri-spell.

\section{Some remarks to literary sources - Pliny the Elder}

For the purpose of basic comparison and descriptions of animal ingredients in the sphere of magic, Pliny the Elder's Historia Naturalis is the closest to PGM in its technicality. It could serve as a great example of the papyri's equivalent in the classical literature. Pliny also mentions use of animal ingredients in spell-like healing recipes. He is one of many classic authors discussing the use of animals similar to magic. In his Natural History, he mentions many different kinds of animals, domestic and wild, common and foreign, quoting many different sources, from historians to mages themselves.

Pliny's main focus is on healing properties of certain animals, but he states that some of this knowledge is based on claims of magicians, which he sometimes disregards as false, depicting them in a very negative fashion. Plin. NH 28. 25: "The frivolous lies of the magicians assert that persons who are anointed with lion's fat, will more readily win favor with kings and peoples...". Plin. NH 28. 27: "In addition to all this, so full of quirks and subtleties are the vain conceits of the magicians" or in the same chapter "...and such are the frivolous and absurd conceits of the professors of the magic art". But it is known he believed in power of herbs and thought they were given to the people by gods. ${ }^{35}$ Luck (2006: p. 69) states: "Pliny's conclusion, however, is cautious: though magic is ineffective and infamous (intestabilis), it nevertheless contains at least 'shadows of truth' (veritatis umbras) that are due to the 'arts of making poisons' (veneficae artes)". So, Luck later states, Pliny believed more in the importance of the ingredients than in the magical ritual itself and even though he doubted the powers of some spells and superstitions, he mentions them "just in case". He seems to be very unsure of what to believe himself.

It is unknown what Pliny's exact sources were, but regarding magic, some of his descriptions or phrases are very similar with those used in magical papyri. For example, in Plin. NH 28. 2 he mentions “... Apollonius, again, informs us in his writings, that the most effectual remedy for tooth-ache is to scarify the gums with the tooth of a man who has died a violent death", which is very similar to PGM (PGM I. $247-262^{36}$ or PGM XII. 107-121). ${ }^{37}$

The magical ingredients he is describing in the Natural History are divided into three main categories - human ingredients (e.g. already mentioned human tooth from PGM I. 247-262), animal ingredients (e.g. Plin. NH 28. 29 - fifteen remedies derived from chameleon), and ingredients against certain illnesses (e.g. Plin. NH 28.46 - remedies for diseases of the head, and for alopecy). It is interesting he is including human ingredients in the same manner as animal ingredients, for we cannot find this in PGM - Pliny mentions the use of the blood of gladiators or brains of the infants (Plin. NH 28. 2: "Epileptic

35 Luck (2006: p. 69).

36 "Take an eye of an ape or of a corpse that has died a violent death".

37 "Take a completely black cat that died a violent death, make a strip of papyrus and write with myrrh the following." 
patients are in the habit of drinking the blood even of gladiators ... Others there are, again, who make the marrow of the leg-bones, and the brains of infants, the objects of their research!"), and there are no such ingredients in PGM.

Very interesting is also the choice of animal species in the Natural History. Pliny dedicates some of the chapters to elephant, lion, camel, crocodile, hippopotamus or chameleon, which are not part of typical Italian fauna. It is possible that he came across these sources during his stay in province Africa.

When we compare Pliny's ingredients to those used in Greek magical papyri regarding species, they are very different. For example, the most used animal in papyri is the donkey (see section 4.2), but in Pliny's account there is not a section dedicated especially to donkey, or anything that would suggest a donkey's special magical powers, as was shown in the papyri.

It is interesting to compare the animal body parts used as ingredients in Greek magical papyri and those of Pliny's account, because he dedicates a lot of space to their description, especially the use of fat (Plin. NH 28. 37), bile (Plin. NH 28. 40), and blood (Plin. NH 28. 41). As was shown by the data gathered in the statistics, these are the ingredients most used in the papyri as well. However, Pliny states, that especially swine's fat is "the substance held in the next highest esteem" (Plin. NH 28. 37), but there is no account of swine's fat in the papyri, although we can find the fat of 5 other animals (dove, goose, sheep, goat $/ 4 \mathrm{X} /$, cow $/ 3 \mathrm{X} /$ ). Regarding the gall, Pliny states, that it is "the most efficacious of all" (Plin. NH 28. 40), especially "the gall of smaller animals" (ibidem). This curiously corresponds with the papyri, where we can find the gall of mostly small animals: the owl (PGM IV. 26-51), chicken (PDM XIV. 701-705), goat 2X (PGM VII. 149-154, PDM XIV. 1026-1045), pig (PGM VII. 191-192), weasel 3X (PDM XIV. 376-394, PDM XIV. 743-749, PDM XIV. 727-36), snake 2X (PDM XIV. 737-738, PDM XIV. 917-919), eel (PGM XXXVI. 283-294), the only larger animal whose gall is used being crocodile (PDM XIV. 1-92). Blood is the most used in the papyri, present in 46 of the spells, but Pliny attributes it mostly poisonous properties, which is not found in the papyri (Plin. NH 28. 41: "Bull's blood too, taken fresh, is reckoned among the poisons"). There is no example of using a bull's blood in PGM.

Probably the most well-known part of Pliny's Natural History is the one in which he describes various uses of hyena body-parts: he accounts on seventy-nine uses of this animal (e.g. using its eyes to cure insanity, backbone marrow to cure sinew pain, liver to cure glaucoma): ${ }^{38}$

... hyaenam magi ex omnibus animalibus in maxima admiratione posuerunt, utpote cui et ipsi magicas artes dederint vimque, qua alliciat ad se homines mentes alienans (Plin. NH 28. 27). ${ }^{39}$

We can see that many of these uses are connected to health, or are attributed healing properties. In the papyri-spells, we can find hyena-ingredient in 5 of them, and only two

38 Ogden (2014: p. 297).

39 "But of all animals, it is the hyæna that has been held in the highest admiration by the magicians, who have gone so far as to attribute to it certain magical virtues even, and the power of alluring human beings and depriving them of their senses." (Riley \& Bostock 1893). 
of those are regarding health issues (others are calling for hyena excrements in love spell - PDM XIV. 1194-1195, hyena heart for vessel divination - PDM XIV. 1-92, or hyena tooth in fragmentary spells - PGM CXXIII. a-f), which is a fairly high number, considering only 8 of all papyri-spells with animal ingredients are regarding health issues. Namely they are requiring hyena tooth against the cough. ${ }^{40}$ We cannot find this use of hyena tooth in Pliny, even though it is described to be used in multiple ways. However, since we have only 5 hyena-ingredient in papyri-spells, it could hardly provide any relevant statistical results (they contain use of either hyena skin, dung, tooth, or heart). Also, all of these five spells are either very short, or only fragmentary. ${ }^{41}$

\section{Pliny vs. the Greek magical papyri}

When we compare Pliny's account of animal ingredients to the Greek magical papyri, we can see that there are certain elements which cannot be found anywhere in Pliny's work, mainly the invocation, which is the part of the papyri-spell that was supposed to be spoken, and Pliny doesn't mention it at all. Another difference is how precisely the ingredients were described. Pliny mentions a lot of them, but the amount of information he provides is limited. Usually it is only the name of an ingredient and general information that it is used for, but there is no exact list of the steps, as we can find in the papyri. Papyri, on the other hand, don't provide us with clearly distinguished descriptions of animals in categories by species - which is typical for literature and Pliny's encyclopedic style, which was better suited for his intended audience, while PGM lack his hierarchy, since they are only a collection of various spell-recipes. The aim of Pliny's texts was education, while papyri were oriented on practical use and therefore were more descriptive. Also, Pliny's choice of animals is very unexpected and suggests his sources were, similar as Greek magical papyri, of foreign origin. Despite his negative opinions on magic mentioned above, he agrees that it has "an immense cultural influence, historical persistence and worldwide reputation" (Otto \& Stausberg 2014: p. 24).

\section{Conclusion}

Based on the research conducted into animal ingredients in Greek Magical Papyri, it was possible to answer the intended research questions. Animal ingredients are present in 142 papyri, which is high enough number of texts to conclude statistical research. Most used animal ingredients were from Equus Africanus Asinus, which could be because of multiple reasons, but it is very probable that this animal was considered as having more magical properties than other species. The most used animal part was determined to be animal body as a whole, which was explained to be mainly because of its function as

40 Other (not health-oriented) hyena spells are calling for hyena's excrements (PDM XIV. 1194-1195), tooth (PGM CXXIII. a-f) and heart (PDM XIV. 1-92).

41 For more on hyena in antiquity see Kitchell (2014: p. 92). 
an offering within the spell. Besides that, the most used actual body part was determined to be blood, because of its magical properties and the belief that it is a source of life energy. From the literary part of the research it was determined that Pliny's sources were in fact accounts of the magicians, as he states himself, but we can also assume that because of the similar structure of Pliny's recipes. Pliny's text is, however, aimed at a different audience and it is a different genre than the papyri, that is why it doesn't use some parts of papyri spells. It is important to continue researching Greek Magical Papyri, for they can show us actual magical practices in antiquity. Their comparison to other written sources, for example the accounts of classical authors, can tell us a lot about not only magic, but religion as well. The next part of the research is going to be aimed at comparison of PGM with other literary sources, which will determine how ancient authors saw magic and how much they knew about it. Research into Greek magical papyri has proven the importance of animals for the spells and magic and also showed that some animals were used with greater frequency, which with later research of literary sources could prove they were considered having more magical attributes than the others.

Figure 1. Number of papyri-spells containing animal ingredient

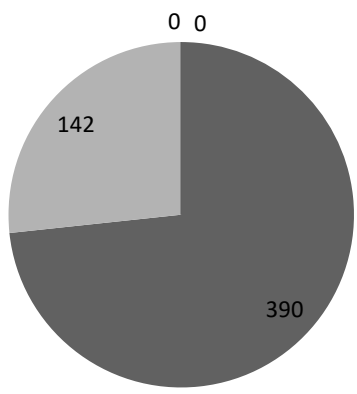

not present $-73,31 \% \quad$ present $-26,69 \%$

Figure 2. Animals as ingredients by species

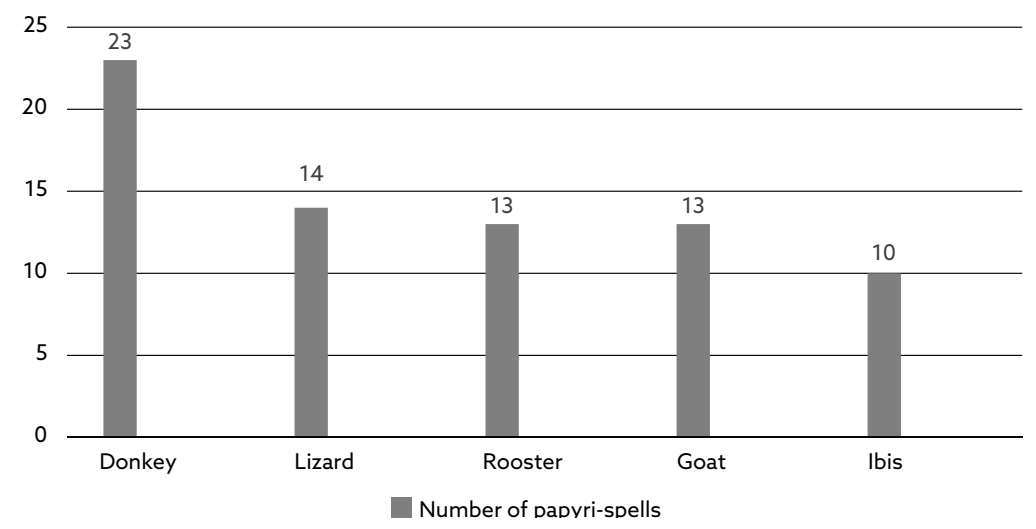


Figure 3. Animals as ingredients by body parts

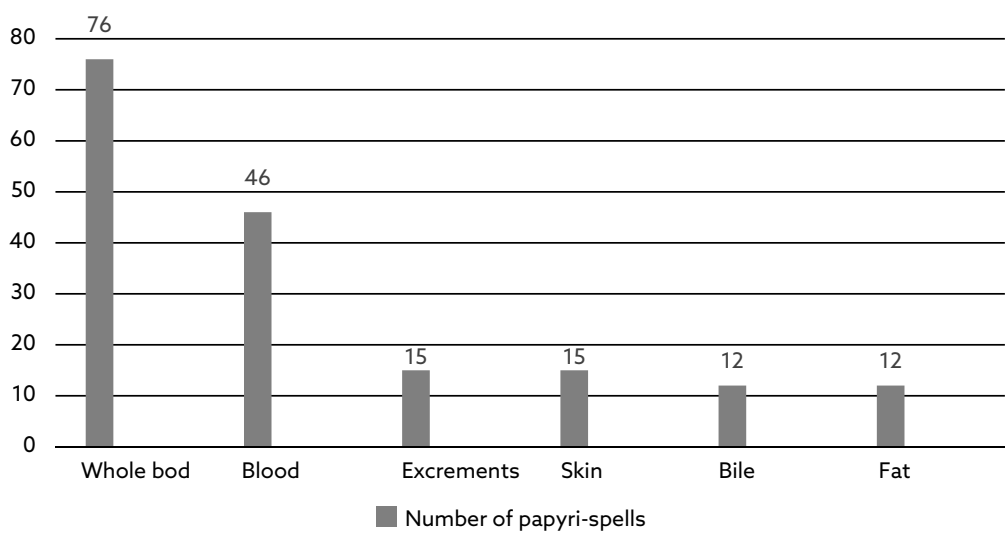

\section{Bibliography}

\section{Primary sources}

Audollent, A. (Ed.). (1904). Defixionum Tabellae quotquot innotuerunt tam in Graecis orientis quam in totius occidentis partibus praeter Atticas in Corpore inscriptionum Atticarum editas. Paris: Fontemoing. Betz, H. D. (Ed.). (1986). The Greek magical papyri in translation: including the Demotic spells. Chicago: University of Chicago Press.

Bonner, C. (1950). Studies in magical amulets, chiefly Graeco-Egyptian. Ann Arbor: University of Michigan Press.

Gager, J. G. (1992). Curse tablets and binding spells from the ancient world. New York: Oxford University Press.

Michel, S. (2001). Bunte Steine - dunkle Bilder: „magische Gemmen“(Katalog, Museum für Kunst und Gewerbe Hamburg, 8. April - 29. April 2001). München: Biering \& Brinkmann.

Müller, L. (Ed.). (1928). Phaedri Augusti Liberti Fabulae Aesopiae. Lipsiae: In aedibus B. G. Teubneri. Preisendanz, C., \& Henrichs, A. (Eds.). (1973). Papyri Graecae magicae: Die griechischen Zauberpapyri (2. ed.). Stutgardiae: In aedibus B. G. Teubneri [1. ed. Lipsiae: Teubner 1928].

Riley, H. T., \& Bostock, J. (Eds.). (1893). Natural history of Pliny. London: D. L. Bell and Sons.

Wünsch, R. (Ed.). (1897). Defixionum tabellae Atticae (Appendix continens defixionum tabellas in Attica regione repertas, Inscriptiones Graecae, III, 3). Berolini: Reimer.

\section{Secondary sources}

Betz, H. D. (1997). Magic and Mystery in the Greek Magical Papyri. In C. A. Faraone, \& D. Obbink (Eds.), Magika hiera: ancient Greek magic and religion (pp. 244-259). New York: Oxford University Press. Bough, J. (2011). Donkey. London: Reaktion Books. 
Bremmer, J. (2007). Ritual. In S. I. Johnston (Ed.), Ancient religions (pp. 32-44). Cambridge, MA: The Belknap Press of Harvard University Press.

Brodňanská, E. (in print). „Oslie bremená“ na pleciach vladárov v spise Jána Webera Lectio principum (1665). In Ideológia v premenách času v pamiatkach gréckej a latinskej tradície. Medzinárodná konferencia pri priležitosti sedemdesiatin profesora Daniela Škovieru; 18. -19. novembra 2016. Bratislava: FiF UK.

Campbell, G. L. (2014). The Oxford handbook of animals in classical thought and life. Oxford: Oxford University Press.

Ciraolo, L. J. (2001). Supernatural Assistants in the Greek Magical Papyri. In M. W. Meyer, \& P. A. Mirecki (Eds.), Ancient Magic and Ritual Power (pp. 279-295). Boston: Brill Academic Publishers.

Dickie, M. W. (2003). Magic and magicians in the Greco-Roman world. London: Routledge.

Ekroth, G. (2014). Animal sacrifice in antiquity. In G. L. Campbell, The Oxford handbook of animals in classical thought and life (pp. 324-354). Oxford: Oxford University Press.

Faraone, C. A. (1991). Binding and burying the forces of evil: the defensive use of "Voodoo dolls" in ancient Greece. Berkeley, CA: University of California Press.

Faraone, C. A., \& Obbink, D. (1997). Magika hiera: ancient Greek magic and religion. New York: Oxford University Press.

Johnston, S. I. (Ed.). (2007). Ancient religions. Cambridge, MA: The Belknap Press of Harvard University Press.

Kitchell, K. F. (2014). Animals in the ancient world from A to Z. New York: Routledge.

Luck, G. (2006). Arcana Mundi. Magic and the Occult in the Greek and Roman Worlds: A Collection of Ancient Texts (2. ed.). Baltimore: Johns Hopkins University Press.

Meyer, M. W., \& Mirecki, P. A. (Eds.). (2001). Ancient Magic and Ritual Power. Boston: Brill Academic Publishers.

Minniyakhmetova, T., \& Velkoborská, K. (Eds.). (2015). The Ritual Year, 10: Magic in Rituals and Rituals in Magic. Innsbruck: ELM Scholarly Press.

Mirecki, P., \& Meyer, M. (Eds.). (2002). Magic and Ritual in the Ancient World. Leiden: Brill.

Ogden, D. (2014). Animal magic. In G. L. Campbell, The Oxford handbook of animals in classical thought and life (pp. 294-309). Oxford: Oxford University Press.

Olsen, S. L. (Ed.). (1996). Horses through time. Boulder, CO: Roberts Rinehart for Carnegie Museum of Natural History.

Otto, B. (2013). Towards Historicizing "Magic" in Antiquity. Numen, 60(2-3), 308-347.

Otto, B., \& Stausberg, M. (2014). Defining Magic. Hoboken: Taylor and Francis.

Rossel, S. et al. (2008). Domestication of the donkey: Timing, processes, and indicators. Proceedings of the National Academy of Sciences, 105(10), 3715-3720.

Sánchez Natalías, C. (2015). Magical Poppets in the Western Roman Empire: A Case Study from the Fountain of Anna Perenna. In T. Minniyakhmetova, \& K. Velkoborská (Eds.), The Ritual Year, 10: Magic in Rituals and Rituals in Magic (pp. 194-202). Innsbruck: ELM Scholarly Press.

Struck, P. (2014). Animals and divination. In G. L. Campbell, The Oxford handbook of animals in classical thought and life (pp. 310-323). Oxford: Oxford University Press.

Urbanová, D. (2014). Latinské proklinaci tabulky na území řimského impéria. Brno: Host.

Versnel, H. S. (1991). Some Reflections on the Relationship Magic - Religion. Numen, 38(2), 177-197. 
Animals as Magical Ingredients in Greek Magical Papyri: Preliminary Statistical Analysis ...

Versnel, H. S. (2002). The Poetics of the Magical Charm: An Essay on the Power of Words. In

P. Mirecki, \& M. Meyer (Eds.), Magic and Ritual in the Ancient World (pp. 105-156). Leiden: Brill.

Mgr. Andrea Salayová / asalayova@gmail.com

Department of Classical Studies

Masaryk University, Faculty of Arts

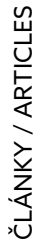

Arna Nováka 1, 60200 Brno, Czech Republic 